\title{
DOI: http://dx.doi.org/10.33846/sf11303
}

Evidence Based Faktor yang Berhubungan Dengan Kualitas Hidup Pasien PPOK Stabil: A Systematic Review

Ulfa Nur Rohmah

Fakultas Keperawatan, Universitas Airlangga; ulfa.nur.rohmah-2018@fkp.unair.ac.id

Muhammad Amin

Fakultas Kedokteran, Universitas Airlangga; amin.fkua@gmail.com

Makhfudli

Fakultas Keperawatan, Universitas Airlangga; ievut_rz@yahoo.com (koresponden)

\begin{abstract}
Background: Low quality of life in chronic obstructive pulmonary disease is crucial because leads to a high risk to reduced activity of daily and mortality. Objective: To identify determine factors that influence with health-related quality of life on stable COPD patients. Method: The database was performed article from Science Direct, CINAHL, Scopus dan PubMed is limited to the last 5 years of publication from 2014 to 2019 , full-text article in English. The keywords used "Health-Related Quality of Life", "AND”, "Stable”, "AND”, "COPD”. Results: Fourteen articles with 8401 participants were included in the review. Most studies were cross sectional design. COPD Assasment Test (CAT) was to assess health-related quality of life in stable COPD. There was symptoms and exacerbation, functional capacity exercise, psychology, sociodemography, biomolecular, comorbidity, and pulmonary function affecting health-related quality of life on stable COPD patients. Conclusion: Factors might affect with poor HRQOL because the condition of COPD itself which then give an effect to whole body. Suggestion: Health worker need to be aware and control of the complexity of factors influence health-related quality of life to impove outcomes for COPD patients.
\end{abstract}

Keywords: health-related quality of life; chronic obstructive pulmonary disease

\section{ABSTRAK}

Latar belakang: Kualitas hidup yang rendah pada pasien Penyakit Paru Obstruktif Kronik (PPOK) menjadi penting karena dapat menyebabkan penurunan aktivitas sehari-hari dan kematian. Tujuan: Untuk mengetahui determinan faktor yang dapat mempengaruhi kualitas hidup pasien PPOK yang stabil Metode: Database yang digunakan dalam penelitian ini adalah Science Direct, CINAHL, Scopus dan PubMed terbatas untuk publikasi 5 tahun terakhir dari 2014 hingga 2019, full text article dengan berbahasa Inggris. Kata kunci yang digunakan adalah ""Health-Related Quality of Life", "AND", "Stable", "AND”, “COPD”. Hasil: Systematic review ini menggunakan 14 artikel dengan 8401 responden. Kuesioner yang digunakan dalam studi adalah COPD Assasment Test (CAT). Tanda gejala dan eksaserbasi, kapasitas latihan fungsional, psikologi, sosiodemografi, biomolekul, komorbiditas dan faal paru mempengaruhi kualitas hidup pasien PPOK stabil. Kesimpulan: Banyak faktor yang mungkin memiliki hubungan dengan kualitas hidup pasien buruk karena kondisi penyakit PPOK itu sendiri yang kemudian berdampak pada seluruh tubuh. Saran: Petugas kesehatan perlu menyadari dan mengontrol kompleksnya dari faktor-faktor yang mempengaruhi kualitas hidup pasien PPOK sehingga menjadi membaik.

Kata kunci: kualitas hidup; penyakit paru obstruktif kronik

\section{PENDAHULUAN}

Penyakit Paru Obstruktif Kronik (PPOK) memiliki karakteristik hambatan yang terjadi pada saluran pernapasan akibat pada saluran pernapasan dan alveolar terjadi kelainan yang signifikan. Hal tersebut disebabkan suatu pajanan dari partikel atau gas $^{(1)}$. Meskipun PPOK memiliki manajemen pengobatan tersendiri, PPOK masih menjadi tantangan kesehatan di masyarakat yang penting karena prevalesinya terus meningkat setiap tahun akibat pajanan dari faktor risiko seperti merokok, tembakau, polusi udara baik dari dalam dan luar ruangan serta lansia ${ }^{(2)}$. Data global tahun 2016 mencatat PPOK menjadi penyebab utama kematian yang ke empat bagi laki-laki dan perempuan di dunia ${ }^{(3)}$.

Bertahun-tahun perkembangan riset yang dilakukan pada kualitas hidup dari sisi medis terus dilakukan. Perkembangan yang paling besar laporan yang berpusat pada penyakit kronis, yakni salah satunya PPOK. Karakter penyakit yang bersifat kronik dan progresif sering kali memiliki pengaruh dan prognosis yang negatif sehingga menjadi alasan terjadinya penurunan kualitas hidup pasien ${ }^{(4)}$. Kualitas hidup pasien PPOK diketahui menurun yang ditandai dengan derajat tingkat penyakit dan sesak napas yang berat ${ }^{(5)}$. Manifestasi gejala PPOK mengakibatkan dampak negatif pada tingkat aktivitas fisik pasien ${ }^{(6)}$. Pada pasien PPOK sering tidak adekuat dalam memenuhi activity of daily living seperti makan, berjalan, berpakaian dan mandi. Keterbatasan fisiologi dan gejala sesak napas memiliki peran terhadap penurunan activity of daily living pada pasien $\mathrm{PPOK}^{(7)}$. Kualitas hidup menjadi sangat penting dalam membuat manajemen PPOK sehingga menjadi esensial untuk mengidentifikasi dan menilai hal tersebut ${ }^{(8)}$.

Beberapa penelitian sebelumnya telah dilakukan penelitian mengenai kualitas hidup PPOK yang menurun. Namun sayangnya masih banyak terdapat kesenjangan yang dihasilkan dan belum dituntaskan. Sehingga studi ini dilakukan untuk menganalisis secara mendalam dan terbaru tentang determinan faktor yang dapat mempengaruhi kualitas hidup pasien PPOK yang stabil. 
Tujuan dari systematic review ini yaitu untuk mengetahui determinan faktor yang dapat mempengaruhi kualitas hidup pasien PPOK yang stabil.

\section{METODE}

Artikel yang diidentifikasi menggunakan mesin pencari database online yakni Science Direct, CINAHL, Scopus dan PubMed. Kata kunci yang digunakan pada pencarian artikel ini adalah "Health-Related Quality of Life", "AND", "Stable", "AND", "COPD". Studi menggunakan pendekatan Preferred Reporting Items for Systematic Reviews and Meta-Analyzes (PRISMA). Semua studi yang tidak memiliki kolerasi dikeluarkan dan studi yang sama dihapus. Artikel dalam bentuk teks lengkap yang memenuhi syarat dianalis. Kriteria inklusi yang ditetapkan sebagai penilaian layak artikel teks lengkap adalah (1) dalam bahasa inggris, (2) full text, (3) desain cross sectional dan dipublish antara tahun 2014-2019, (4) artikel menggunakan kuesioner kualitas hidup khusus PPOK seperti St George's Respiratory Questionnaire (SGRQ), SGRQ for COPD (SGRQ-C), Chronic Respiratory Disease Questionnaire (CRQ), Short Form Chronic Respiratory Disease Questionnaire (SF-CRQ), Clinical COPD Questionnaire (CCQ), COPD Assesment Test (CAT), The Breathlessness Cough and Sputum Scale (BCSS), (The m-MRC, The Medical Research Council (MRC) Dyspnea Scale, Baseline Dyspnea Index and Transition Dyspnea Index). Artikel yang dikeluarkan dari studi ini adalah arikel dengan desain eksperimental dan perbandingan antara kualitas hidup dan penyakit serta pasien PPOK eksaserbasi akut.

Proses pencarian di mulai pada bulan Desember 2019-Januari 2020. Artikel yang digunakan disesuaikan dengan kriteria inklusi dan eksklusi, artikel yang ditemukan akan dipilih oleh peneliti dan disintesis sesuai dengan tema yang digunakan. Artikel yang sudah sesuai kemudian dianalisis dan dibahas berdasarkan poin - poin yang ditetapkan.

\section{HASIL}

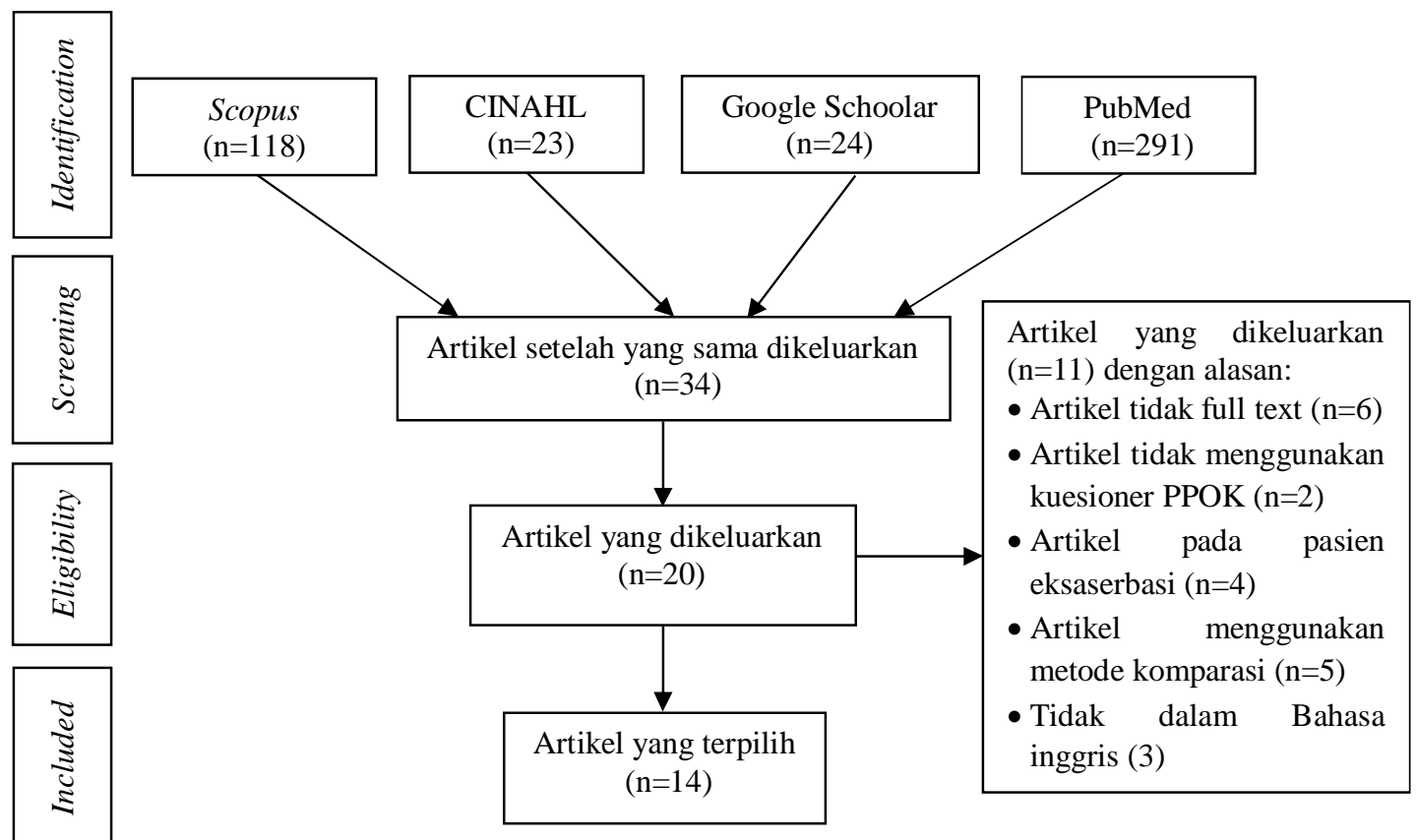

Gambar 1. Diagram flow dan pemilihan artikel

Pencarian literatur awal menghasilkan 456 artikel (118 dari Scopus, 23 dari CINAHL, 24 dari Google schoolar, 291 dari Pubmed). Setelah meninjau abstrak untuk melakukan relevansi dan kesesuaian dengan kriteria inklusi, 34 artikel dipilih untuk ulasan teks lengkap. Ada 20 artikel teks lengkap dikecualikan dengan alasan sesuai dengan karena tidak dalam bentuk full text, menggunakan metode komparasi, artikel membahas pada pasien eksaserbasi, bahasa yang digunakan dalam full text tidak berbahasa Inggris. Akhirnya, 14 artikel dipilih untuk ditinjau, seperti yang tercantum dalam gambar 1.

Studi dalam sytematic review ini menggunakan metode yang homogen. Terdapat 14 artikel menggunakan studi desain cross sectional. 14 artikel terbit pada tahun 2014 sampai 2019. Besar jumlah responden dalam studi ini sebanyak 8401 dengan rata-rata besar sampel sebesar 600 responden per artikel. Kuesioner yang digunakan untuk mengukur kualitas hidup pada studi ini beragam. Kuesioner yang paling banyak digunakan untuk mengukur kualitas hidup pasien PPOK adalah COPD Assasment Test (CAT) ${ }^{(9),(10),(11),(12),(13),(14),(15)}$. Kualitas hidup pasien PPOK stabil dipengaruhi oleh banyak beberapa faktor. Faktor tersebut dikategorikan menjadi tanda gejala penyakit dan eksaserbasi ${ }^{(9),(12),(16),(17),(18),(19),(20),(21)}$, kapasitas latihan fungsional $^{(9),(13),(14),(17),(18)}$, 
psikologi $^{(9),(18),(20),(21),(22)}, \quad$ sosiodemografi ${ }^{(11),(13),(15),(16),(17)}, \quad$ biomolekular $^{(10)}, \quad$ komorbiditas $^{(9),(17),(20)}$, dan faal $\operatorname{paru}^{(9),(16),(17),(20),(21)}$.

\section{PEMBAHASAN}

Berdasarkan evidence yang telah ditemukan pada pasien PPOK, tanda gejala dan eksaserbasi menjadi faktor dominan yang berpengaruh dalam kualitas hidup pasien PPOK stabil. Sesak napas dan skor CAT yang tinggi memiliki hubungan negatif yang dilaporkan memiliki kualitas hidup yang rendah ${ }^{(9)(12)(17)(19)(21)}$ yang berdampak pada pembatasan aktivitas sehari-hari ${ }^{(18)}$ namun kontras dengan studi lain memiliki tanda dan gejala rendah memiliki kualitas hidup yang rendah karena mengkaji gejala pada saat tahap awal penyakit yang berbasis di rumah ${ }^{(16)}$. Gejala lain yang ikut mempengaruhi kualitas hidup yang rendah berupa gejala disfagia yang memiliki sensasi makanan tersangkut di tenggorokan atau dada atau pada bagian belakang sternum, batuk saat makan, makan atau minum salah pada saat makan menjadi masalah umum pada pasien PPOK ${ }^{(12)}$. Batuk kronis dan produksi sputum diketahui berdampak pada penurunan kualitas hidup, khususnya mengkaji batuk 7 hari sebelumnya lebih akurat mengidentifikasi penurunan kualitas hidup pada pasien PPOK daripada bronkitis kronik $^{(20)}$. Eksaserbasi yang tinggi dikaitkan dengan penurunan kualitas hidup ${ }^{(17)(20)}$, pasien yang memiliki lebih dari atau 2 kali hospitalisasi cenderung kualitas hidup menjadi rendah ${ }^{(9)}$, hal ini berkaitan dengan tingkat keparahan penyakit dan status kesehatan pasien ${ }^{(18)}$. Gejala pasien dengan diikuti lebih banyak terjadi eksaserbasi akan berdampak kualitas hidup yang semakin buruk ${ }^{(21)}$. Eksaserbasi tinggi penting untuk dicegah agar dapat meningkatkan kualitas hidup dan mengurangi beban biaya perawatan ${ }^{(19)}$.

Kapasitas latihan fungsional memiliki hubungan dengan kualitas hidup. Pasien yang memiliki jalan kurang dari 360 meter memiliki kualitas hidup yang rendah ${ }^{(13)}$. Kapasitas latihan fungsional dapat mengevaluasi status pasien PPOK dengan status hiperinflasi paru pasien. Kapasitas latihan juga dapat menggambarkan gejala respirasi dalam kehidupan sehari-hari ${ }^{(14)}$. Kualitas hidup yang menurun bisa terjadi akibat kapasits fungsional yang dipengaruhi komposisi tubuh otot dan lemak atau dukungan sosial yang rendah dan tantangan yang tinggi sehingga kurang berlatih ${ }^{(18)}$. Peningkatan aktivitas fisik memiliki hubungan positif dengan kualitas hidup yang tinggi sehingga memiliki peran penting pada kehidupan sehari-hari ${ }^{(9)}$.

Faktor psikologi yang terdiri dari depresi dan kecemasan memiliki kaitan erat dengan kualitas hidup pada pasien PPOK. Psikologi berupa kecemasan dan depresi yang tinggi menurunkan kualitas hidup ${ }^{(9)(20)(21)}$, studi lain menyatakan hanya kecemasan saja yang berhubungan dengan kualitas hidup ${ }^{(22)}$. Sisi psikologis ini berpotensi mengakibatkan penurunan faal paru, persepsi pengalaman pasien terhadap penyakit yang di deritanya ${ }^{(9)}$, melibatkan psikologis pada gangguan penyakit pernapasan sehingga petugas kesehatan harus bisa menilai psikologis pada pasien PPOK $^{(18)}$.

Sosiodemografi masih memiliki berbagai kontroversi dalam mempengaruhi kualitas hidup pasien PPOK. Status merokok memiliki hubungan negatif yaitu bukan perokok memiliki kualitas hidup yang lebih baik daripada perokok atau mantan perokok. Perokok dan mantan perokok menjadi pemicu rendahnya kualitas hidup yang berakhir pada gejala eksaserbasi $\mathrm{PPOK}^{(11)}$. Hubungan positif juga ditemukan pada indeks massa tubuh yang tinggi atau obesitas yang memiliki kualitas hidup lebih baik ${ }^{(11)}$, namun kontras bahwa indeks massa tubuh memiliki tinggi memiliki kualitas hidup rendah $^{(17)}$. Sedangkan usia tua memiliki kualitas hidup yang meningkat ${ }^{(16)}$ karena usia muda merasa kurang mampu menghadapi penyakit dan usia tua yang telah lama menderita PPOK merasa sudah bisa beradaptasi dengan hidupnya ${ }^{(13)}$. Sosioekonomi yang rendah juga berdampak pada kualitas hidup yang rendah ${ }^{(16)}$. Namun kontras sisi perbedaan gender tidak berpengaruh pada kualitas hidup pasien PPOK $^{(15)}$.

Segi biomolekuler berupa serum brain natriuretic peptide dan interleukin 6 yang tinggi memiliki dampak pada kualitas hidup yang rendah. Hal ini diakibatkan biomolekuler memprediksi derajat penyakit PPOK. Pasien PPOK yang stabil juga rentan mengalami gagal jantung yang menjadi komorbiditas akibat inflamasi ${ }^{(10)}$. Komorbiditas memiliki hubungan pada kualitas hidup pasien $\mathrm{PPOK}^{(9)(17)}$. Komorbiditas yang sering muncul yakni penyakit kardiovaskular ${ }^{(20)}$. Nilai $\mathrm{FEV}_{1} / \mathrm{FVC}, \mathrm{FEV}_{1}$ prediksi, $\mathrm{D}_{\mathrm{LCO}}, \mathrm{PaO}_{2}$ juga diperhitungkan sebagai faktor berperan pada kualitas hidup ${ }^{(16)(17)(20)(21)}$. Penurunan kualitas hidup yang besar diikuti pasien yang memiliki progres tingkat penyakit dari derajat berat menjadi sangat berat yang artinya semakin menurun juga nilai faal $\operatorname{paru}^{(9)}$.

\section{KESIMPULAN}

Beberapa faktor dapat mempengaruhi kualitas hidup pasien PPOK seperti tanda dan gejala, eksaserbasi, komorbiditas, status merokok, usia, indeks massa tubuh, kapasitas latihan fungsional, dan psikologis. Semua faktor lebih banyak berhubungan dengan penurunan kualitas hidup pasien PPOK akibat kondisi penyakit PPOK itu sendiri yang kemudian berdampak pada seluruh tubuh, namun beberapa ada yang memprediksi meningkatkan kualitas hidup pasien PPOK stabil. Hal ini perlu untuk diobservasi lebih lanjut lagi. Perlunya kesadaran dan kontrol dari petugas kesehatan dan program rehabilitasi paru yang dapat mengurangi eksaserbasi sebagai perburukan dari PPOK stabil sehingga dapat meningkatkan kualitas hidup stabil dan mengurangi risiko mortalitas dan morbiditas. 


\section{DAFTAR PUSTAKA}

1. GOLD. 2020 Report Global Strategy for the Diagnosis, Management, and Prevention of CHronic Obstructive Pulmonary Disease [Internet]. 2020. Available from: www.goldcopd.org

2. Wacker ME, Jörres RA, Karch A, Wilke S, Heinrich J, Karrasch S, et al. Assessing health-related quality of life in COPD: Comparing generic and disease-specific instruments with focus on comorbidities. BMC Pulm Med [Internet]. 2016;16(1):1-11. Available from: http://dx.doi.org/10.1186/s12890-016-0238-9

3. WHO. World Health Statistics Overview 2019 Monitoring Health for Thr SDGs [Internet]. Vol. 6. 2019. 1-46 p. Available from: https://doi.org/10.1016/j.snb.2019.127013

4. Milanowska J, Mackiewicz B, Węgorowski P, Milanowski J, Milanowski P, Makara-Studzińska M. The quality of life of farmers with chronic obstructive pulmonary disease (COPD). Ann Agric Environ Med. 2017;24(2):283-7.

5. Kim SH, Oh YM, Jo MW. Health-related quality of life in chronic obstructive pulmonary disease patients in Korea. Health Qual Life Outcomes. 2014;12(1):1-7.

6. Miravitlles M, Ribera A. Understanding the impact of symptoms on the burden of COPD. 2017;1-11.

7. Ozsoy I, Ozcan B, Kahraman, Acar S, Ozalevli S, Akkoclu A, et al. Factors Influencing Activities of Daily Living in Subjects with COPD. Respir Care. 2018;(September 2016):1-7.

8. Yahya N, Omar N, Daut U, Adznam SA. REVIEW ARTICLE A Systematic Review on Factors Associated with Health-Related Quality of Life among Chronic Obstructive Pulmonary Disease Patients. Malaysian J Med Heal Sci. 2019;15(April):61-8.

9. Esquinas C, Ramon MA, Nuñez A, Molina J, Quintano JA, Roman-Rodríguez M, et al. Correlation between disease severity factors and EQ-5D utilities in chronic obstructive pulmonary disease. Qual Life Res [Internet]. 2019; Available from: https://doi.org/10.1007/s11136-019-02340-4

10. Ghobadi H, Aslani MR, Hosseinian A, Farzaneh E. The correlation of serum brain natriuretic peptide and interleukin-6 with quality of life using the chronic obstructive pulmonary disease assessment test. Med Princ Pract. 2018;26(6):509-15.

11. Wytrychiewicz K, Pankowski D, Janowski K, Bargiel-Matusiewicz K, Dabrowski J, Fal AM. Smoking status, body mass index, health-related quality of life, and acceptance of life with illness in stable outpatients with COPD. Front Psychol. 2019;10(JULY):1-7.

12. Lindh MG, Malinovschi A, Brandén E, Janson C, Ställberg B, Bröms K, et al. Subjective swallowing symptoms and related risk factors in COPD. ERJ Open Res [Internet]. 2019;5(3):1-8. Available from: http://dx.doi.org/10.1183/23120541.00081-2019

13. Dürr S, Zogg S, Miedinger D, Steveling EH, Maier S, Leuppi JD. Daily physical activity, functional capacity and quality of life in patients with COPD. COPD J Chronic Obstr Pulm Dis. 2014;11(6):689-96.

14. Zeng GS, Chen LC, Fan HZ, Wu LL, Wu XP, Fang ZK, et al. The relationship between steps of 6MWT and COPD severity: A cross-sectional study. Int J COPD. 2019;14:141-8.

15. Varol Y, Anar C, Çimen P, Ünlü M, Halilçolar H, Güçlü SZ. Sex-related differences in COPD assessment test scores of COPD populations with or without significant anxiety and/or depression. Turkish J Med Sci. 2017;47(1):61-8.

16. Ahmed MS, Neyaz AN, Aslami A. Health-related quality of life of chronic obstructive pulmonary disease patients: Results from a community based cross-sectional study in Aligarh, Uttar Pradesh, India. Lung India. 2016;33(2):148-53.

17. Corlateanu A, Botnaru V, Covantev S, Dumitru S, Siafakas N. Predicting Health-Related Quality of Life in Patients with Chronic Obstructive Pulmonary Disease: The Impact of Age. Respiration. 2016;92(4):229_ 34.

18. Noonil N, Rewwadee P, Saifon A. Health-related quality of life and related factors in thais with stable COPD. Walailak J Sci Technol. 2019;16(12):955-64.

19. Liang LR, Lin YX, Yang T, Zhang H, Li J, Wang C. Determinants of health-related quality of life worsening in patients with chronic obstructive pulmonary disease at one year. Chin Med $\mathbf{J}$ (Engl). 2014;127(1):4-10.

20. Deslee G, Burgel PR, Escamilla R, Chanez P, Court-Fortune I, Nesme-Meyer P, et al. Impact of current cough on health-related quality of life in patients with COPD. Int J COPD. 2016;11(1):2091-7.

21. Ekici A, Bulcun E, Karakoc T, Senturk E, Ekici M. Factors associated with quality of life in subjects with stable COPD. Respir Care. 2015;60(11):1585-91.

22. Parreira VF, Kirkwood RN, Towns M, Aganon I, Barrett L, Darling C, et al. Is there an association between symptoms of anxiety and depression and quality of life in patients with chronic obstructive pulmonary disease? Can Respir J. 2015;22(1):37-41. 